\title{
A Correlative Study on EFL Students' Binge Watching Behaviors and Their Vocabulary Mastery
}

\author{
Burhanuddin \\ burhanuddin.aba@umi.ac.id \\ Akademi Bahasa Asing UMI \\ Rosmiaty \\ rosmiaty.aba@umi.ac.id \\ Politeknik Sandi Karsa \\ Nurul Fadilah \\ nurulfa22@gmail.com \\ Akademi Bahasa Asing UMI
}

\begin{abstract}
In this study, the writer aims to know the correlation between students habits in watching english movie and their vocabulary mastery of The Fourth Semester Students in ABA-UMI 2017.

The whole population of this study was The Fourth Semester Students of ABA-UMI. The sample was 20 students, the sample is taken by using purposive sampling technique.

Based on the analysis of Data, the students habit in watching English movies, 3 students are in bad category (15\%), 10 students are in fair category $(50 \%), 7$ students are in good category $(35 \%)$, and no students are in very strong category. The vocabulary mastery, there are no students who got score less than 50 (poor category). Furthermore, there are 2 students (10\%) who got score between 50 and 59 (low category); 2 students (10\%) who got score between 60 and 69 (fair category); 10 students (50\% ) who got score between 70 and 79 (good category); and 6 students (30\%) who got score between 80 and 100 (excellent category).

The result revealed that there is correlation between students habit in watching English movies and students' vocabulary mastery. It is suggested that (1) The use of media cannot be separated from teaching and learning process. The use of movie is very helpful in learning process because it can makes more interested to the material and make students learn happily. (2) Hopes that students can improve their English ability independently. For example; by using media to improve their English.
\end{abstract}

Key words: Correlative Study, Students Behaviors, Binge Watch, Vocabulary Mastery

\section{INTRODUCTION}

Language is an important aspect in human life. It is means of communication the persons to the others. The people need language to looking for and give people benefit information. Communication hold the most important aspect of the language, listening or reading cannot occur without communication. People need a language as a communication to express their feeling, thought and desires. 
There are a number of elements of language learning. Vocabulary is the most obvious components and the first thing applied in language as communication. According to Hornby vocabulary is the total number of words, which makes up the language. It can be defined, caught, as the word we teach in the foreign language.

Studying language can started by learning vocabulary first, it is the most important element of language. Vocabulary is central to language and it is important to the language students. Without mastery vocabulary, students cannot communicate effectively and express students ideas in both oral and written form and they listen in order to discovering the meaning of what others say. So, the focus of students English learning process is vocabulary.

As a part of language components, vocabulary has an important role in learning English. Without mastering vocabulary, it is impossible to master English well. The students who get more vocabulary, they can improve their English easily. In senior high school, students will study much about texts, grammar, etc. ideally, they should mastery vocabulary to help writing texts skill, speaking fluently, etc. But in fact, they still find more difficulties in mastery vocabulary. Students have difficulties in enriching their vocabulary. They get difficulties in memorizing the new words, so they limited vocabulary.

In psychology, habituation is an example of non associative learning in which there is progressive diminution of behavioral response probability with repetition of a stimulus. It is another form of integration. An animal first responds to a stimulus, but if subsequent responses. One example of this can be seen in a small cage; the birds initially react to it as thought it were a predator, showing that it is only a very specific stimulus that is habituated to (namely one particular unmoving owl in one place). Habituation has been shown in essentially very species of animals, including the large protozoan stenter coeruleus. Therefore, habitual learning is learning by using repetition in a way of learning. The learners do something continuously and repeatedly and this activity is used as a way in learning something to improve their achievement. Some Indonesian students probably like to use their habits in watching movie to enrich their vocabulary, grammar, pronunciation, spelling, etc.

The habit of binge watching movies provide opportunities to study language about vocabulary. Moreover, students should have a schedule for it is. In order to they can get new vocabularies and find many information about grammar to help language skill. Sometimes they also will find the problems about structure, difficult new vocabulary based on the dialogue by the native speaker. Then, they can look for the solution of the problems by asking to the teacher or look for the other referent. Indirectly, students will study about vocabulary of English by watching movie. This study replicates the research conducted by Ahmad Syafi'i (2013) but there are some differences from the the previous research such as the object of research and the method. This study was conducted in ABA and using qualitative method while the previous research (Ahmad's) was conducted in SMKN 1 Salatiga and using SPSS 16.00 Windows Program to analized the data.

In line with the explanation above, the objective of the study is to find out the correlation between students habit in binge watching English movies and vocabulary mastery of the fourth semester students in ABA-UMI. 


\section{METHOD}

This study employs qualitative method by analyzing the description on students' knowledge about the correlation study between habits in watching English movies and their vocabulary mastery. The population of the study were all students of Akademi Bahasa Asing (ABA) UMI registered in 2017. The samples taken were students of fourth semester of ABA UMI. So, the authors chose 20 students as the sample of this study through random sampling method. The data collection for this study used questionnaires and vocabulary test. The questionnaire consists of 10 questions used to see students' binge-watching habit. After the data from the questionnaire were collected, the test was carried out which consists of several questions or exercises that are used to measure the skills of knowledge, intelligence, ability or attitude of the individual or group. In this scientific research, the writer use narrative text to find out the student's vocabulary mastery. The questionnaire items were classified into three categories, namely good, fair, and bad. Content analysis was used to identify participants' patterns related to certain themes of their perspectives about vocabulary acquisition through online game. The first step of analyzing data was processing the data gathered from the questionnaires. The data collected from close-ended questionnaires were analyzed using Microsoft Excel and SPSS. The researcher find out the score from each item in the questionnaire. Table 1 presents the Likert Scale and the converted score

Table 1 : The Converted Score of the Frequency

\begin{tabular}{|c|c|}
\hline Frequency & The converted Score \\
\hline Poor & 1 \\
\hline Low & 2 \\
\hline Fair & 3 \\
\hline Good & 4 \\
\hline Excellent & 5 \\
\hline
\end{tabular}

In order to get findings in this research, the writer conduct the questionnaire to students. After the questionnaire conducted the writer analyzed and described the data. The writer began by identifying, arranging, and then clarifying the data from the result or questionnaire from the student to know the correlation study between students habits in watching english movie and their vocabulary mastery.

determination strategies, social strategies, memory strategies, cognitive strategies and metacognitive strategies. The data from open-ended questionnaire were also classified into those categories. Next, the statistical data was figured and described by words so that the researcher and the reader would understand the finding

better. 


\section{FINDINGS AND DISCUSSION}

\section{Students' frequency of watching English movies}

The questionnaire is to count the students frequency of watching English movies. There are 10 questions of frequency with and have option always, often, sometimes, seldom, and never. Below is the questionnaire recapitulation of students' frequency of watching English movies. Answer column consist of five columns A, B, C, D, and E which is based how many participants' choices of 10 questions on each answer. Rank is score of answer column, $A=5$, $\mathrm{B}=4, \mathrm{C}=3, \mathrm{D}=2$, and $\mathrm{E}=1$. Count is earned by summing up the scores of ranks. The maximal count is $5 \times 10=50$ and the minimal count is $1 \times 10=10$.

\section{Tabel 4.1}

The Frequency Distribution of the Students Habit in Binge-watching English movie and its Classification

\begin{tabular}{|c|c|c|c|}
\hline Score & Frequency & Percentage & Category \\
\hline $40-50$ & 7 & $35 \%$ & Good \\
\hline $20-39$ & 10 & $50 \%$ & Fair \\
\hline $10-19$ & 3 & $15 \%$ & Bad \\
\hline Total & 20 & $100 \%$ & \\
\hline
\end{tabular}

\section{Students' Vocabulary Mastery}

The writer wants to find out data about the students' vocabulary mastery. In this case, the writer makes a vocabulary test using multiple choice questions.

Tabel 4.2

The Frequency Distribution of the Students Test Result and its classification

\begin{tabular}{|c|c|c|c|}
\hline Score & Frequency & Percentage & Category \\
\hline $0-49$ & 0 & $0 \%$ & Poor \\
\hline $50-59$ & 2 & $10 \%$ & Low \\
\hline $60-69$ & 2 & $10 \%$ & Fair \\
\hline $70-79$ & 10 & $50 \%$ & Good \\
\hline $80-100$ & 6 & $30 \%$ & Excellent \\
\hline Total & 20 & $100 \%$ & \\
\hline
\end{tabular}

\section{Discussion}

Based on the findings, the writer found some information about how the students' habit in watching English movies and vocabulary mastery on the fourth semester students of Foreign Language Academy UMI.

First, the students habit in watching English movies, 3 students are in bad category (15\%), 10 students are in fair category (50\%), 7 students are in good category $(35 \%)$, and no students are in very strong category. The mean score shows that the students habit in watching English movies is in Fair level. 
Secondly, the vocabulary mastery, there are no students who got score less than 50 (poor category). Furthermore, there are 2 students (10\%) who got score between 50 and 59 (low category); 2 students (10\%) who got score between 60 and 69 (fair category); 10 students (50\%) who got score between 70 and 79 (good category); and 6 students (30\%) who got score between 80 and 100 (excellent category). Moreover, based on the mean of the students vocabulary mastery scores it can be concluded that vocabulary mastery on the fourth semester students in Foreign Languge Academy UMI is in good category.

\section{CONCLUSION}

After getting the data which has been analyzed, the writer concludes about the correlation study between students' habits in watching English movie and their vocabulary mastery of the fourth semester students in ABA-UMI. Students' frequency of watching English movies of fourth semester student at Foreign Language Academy can be classified at fair categorized. The writer concludes that there is correlation between students' habit in binge-watching English movies and students' vocabulary mastery because student who always watching English movie can enrich their vocabulary mastery.

\section{REFERENCES}

Ahmad Syafi'i. 2013. Thesis. The Correlation Study Between Students Habit in Watching English Movie and Their Vocabulary Mastery (A Correlational Study of the Second Years Students of SMKN 1 Salatiga in Academic Year of 2012/2013). Salatiga.

Arham, M., Akrab, A.H. (2018). Delving into Delving into Content Lecturers' Teaching Capability in Content Language Integrated Learning (CLIL) at an Indonesian University, Asian ESP Journal, Vol. 14 No. 7.2 (2018).

Arikunto, Suharsimi. 1989. Prosedure Penelitian Suatu Pendekatan Praktik. Jakarta: PT. Bina Aksara.

Glolier, 1981. The Glolier International Dictionary. Maynord Massachussetts inc: United States of America.

Hadi, Sutrisno.1979. Metodologi Research. Yogyakarta: Universitas Gajah Mada.

Hatch, Evelyn, and Brown, Cheryl. 1958. Vocabulary Semantic s and Language. Cambridge University Press, California,

Hornby. 1985. Oxford Advanced Learners Dictionary of Current English. New York: Oxford University Press. 1995. Oxford Advanced Learners Dictionary. Oxford: Oxford University Press.

Jannah, H., Sumirna, S., \& Nurhikmawati, N. (2016). Language Styles of Advertisements In High End Magazine. Tamaddun, 15(2), 65-72.

Margono. 2004. Metodologi Penelitian Pendidikan. Jakarta: Rineka Cipta.vol I, Oxford Learners Pocket Dictionary. New York: Oxford University Press.

Mbato, C. L. (2020). Graduate Students' Perceptions on their Self-Efficacy in Writing Academic Papers. ELT WORLDWIDE, 7(1), 31-41.

Scrivener, Jim. 1994. Learning Teaching. New York: Heinemann.

Thomas, Diana. 1995. Flexible learning strategies in higher and further education. Cassel. London. 